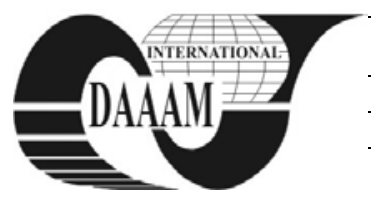

Annals of DAAAM for 2011 \& Proceedings of the 22nd International DAAAM Symposium, Volume 22, No. 1, ISSN 1726-9679 ISBN 978-3-901509-83-4, Editor B. Katalinic, Published by DAAAM International, Vienna, Austria, EU, 2011 Make Harmony between Technology and Nature, and Your Mind will Fly Free as a Bird Annals \& Proceedings of DAAAM International 2011

\title{
PRODUCTION PLANNING STRATEGIES USING A DATA BASE INTEGRATE SYSTEM
}

\author{
SERBAN, R[aul] \& CALIN, O[ana] A[ndreea]
}

\begin{abstract}
This paper present the possibility to develop a data base integrated system used for production planning strategies. Our study could offer economical advantages such new production structures, new control policies and low costs. This paper proposes a new vision for creating a database integrated system for developing a production planning strategies. Topics to be discussed will include: production planning, data base system, manufacturing.

Key words: production planning, data base, informatics flow
\end{abstract}

\section{INTRODUCTION}

The production planning strategy development using a data base integrate system will improve technical solutions and product quality. A data base integrated system could generate information about production decisions, control policies, the waiting times and obstruction points.

This paper present the development of a data base integrated system used to generate production planning in a flexible manufacturing system. Using a data base integrated system will offer two important advantages. The first advantage is represented by a better production resource by eliminating bottlenecks and the second advantage is improving the productivity of existing manufacturing systems (Mohora at all, 2009). The parameters that describe production planning strategy are:

- The production operations: describes the type of the products for which the machines can be used in the production process

- Period of time between production actions

- Production efficiency: measures the percentage of high quality products

- Processing time: is the necessary time for current processing of every machine.

\section{THE DATA BASE INTEGRATE SYSTEM DEVELOPMENT}

The development of data base integrates system will be divided in five steps.

The first step contains the integration study of the informatics flow in production process.

Production design module is very important because this component should be individualized to the needs of each user. Most manufacturing systems of the enterprise may be based on a general structure, independent by nature of the work carried out by a firm. Production system, however, must work perfectly and respond effectively to every user on their needs.

Production process is based on informatics flow, whether a company manufactures auto components, IT components, food or clothes, etc.

Following and respecting informatics flow scheme is the first step for all companies to create the best integration between their activity and the standards used. Informatics flow scheme is shown below.

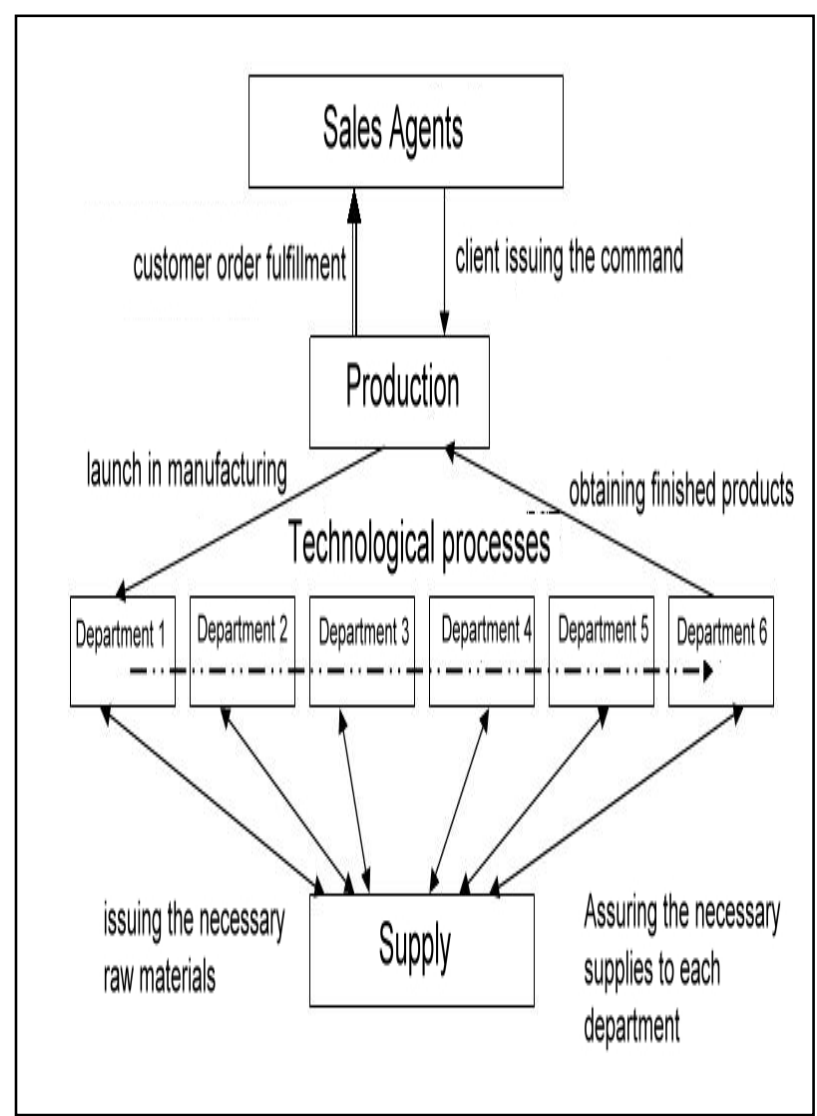

Fig. 1. Production informatics flow

For the second step we propose to build a structure of a modern data base integrated system like in the scheme below.

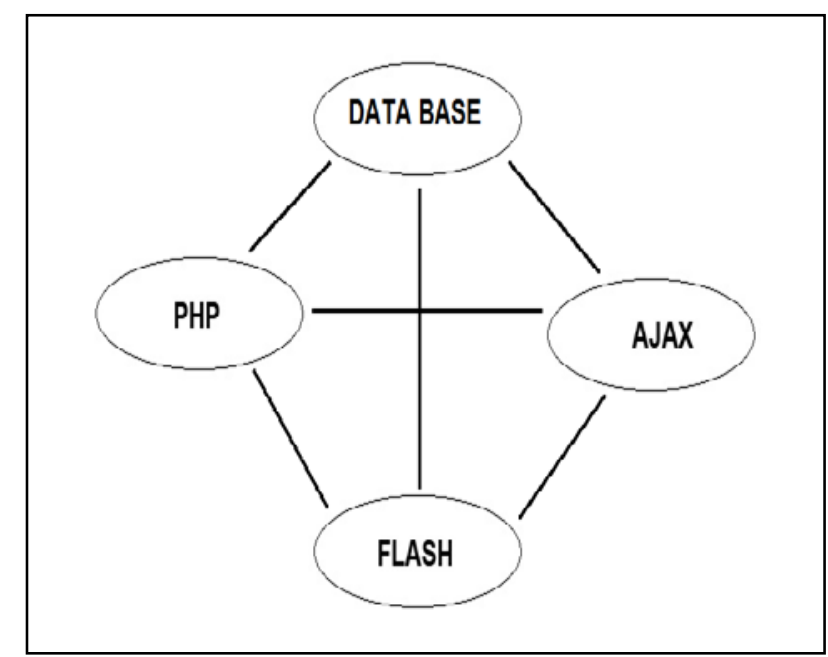

Fig. 2. Collaboration of various programming language and databases 
The data base integrated system will contain one server, specialized software based on AJAX, PHP with data base and a Broadband connection.

The advantage will be that the system access is possible from all over the world, and the data will be seen in real time. Our research presents in figure 3 a solution to develop a data base integrated system with new specifications for universal use on various devices.

The new solution will allow developing individual production plan, scheduling and arranging the development in production time in order to enable a real time simulation for a production.

For the third step we propose a database structure presented in figure 3.

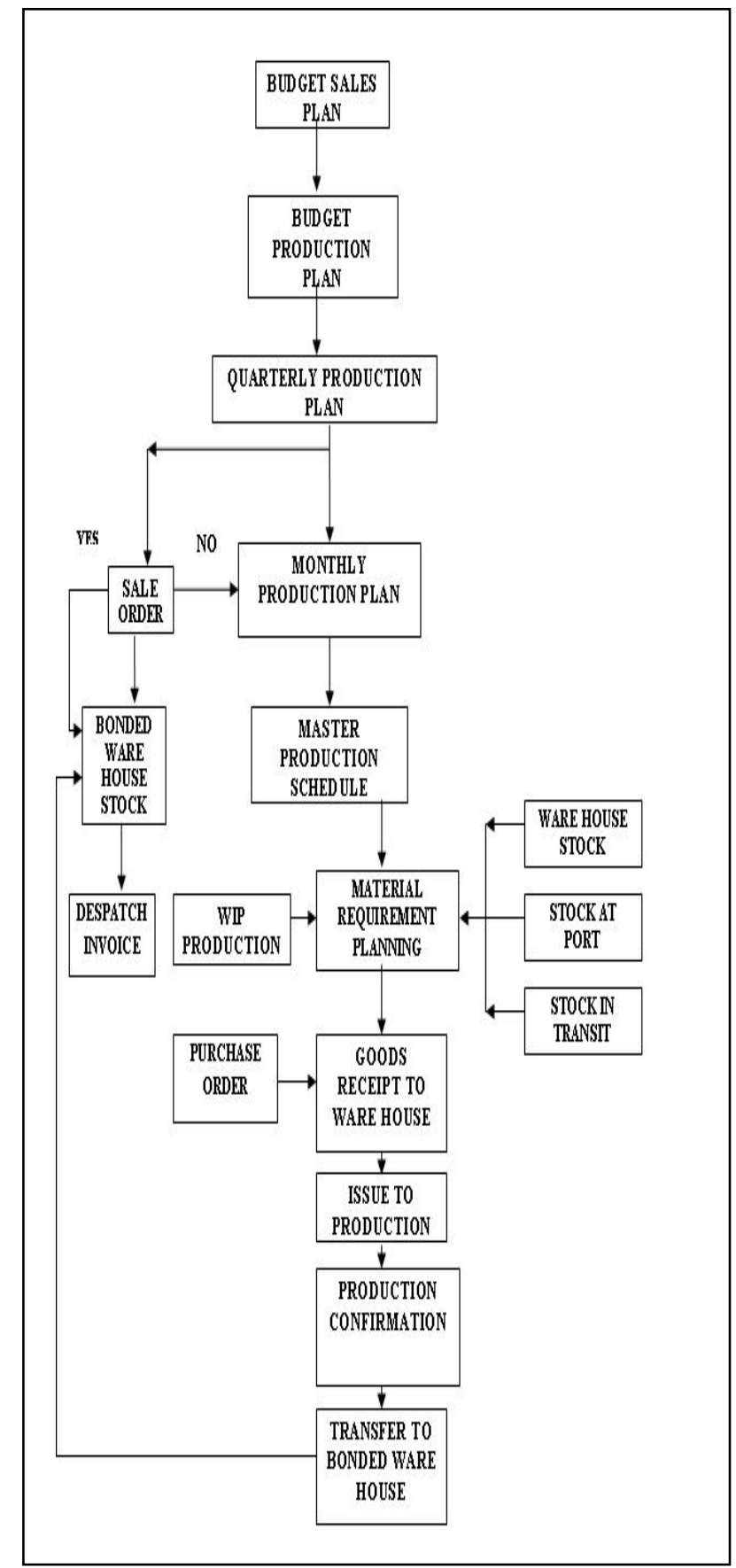

Fig. 3. Data base block scheme

Figure 3 shows the direct connection with our informatics flow for production process presented in figure 1 . The most important data (database variables) used in our production planning are:
- Orders from clients for a period of time

- Production capability for a period of time

- Necessary supplies for a period of time

- Human resources for a period of time.

The fourth step will calculate the data variables using Linear Programming Model. We are going to use the following decision variables:

- $\mathrm{p}_{\text {it }}$ production of the item $\mathrm{i}$ during time period $\mathrm{t}$

- $\mathrm{q}_{\text {it }}$ inventory data for the item $\mathrm{i}$ in a period of time $\mathrm{t}$. Also we are going to use the following the parameters:

- $\mathrm{T}, \mathrm{I}, \mathrm{K}$ number of time periods, items, resources, respectively

- $\mathrm{a}_{\mathrm{ik}}$ amount of resource $\mathrm{k}$ required per unit of production of item i

- $\mathrm{b}_{\mathrm{kt}}$ amount of resource $\mathrm{k}$ available in a period of time $\mathrm{t}$

- $\mathrm{d}_{\mathrm{it}}$ demand for the item $\mathrm{i}$ in a period of time $\mathrm{t}$

- $\quad \mathrm{cp}_{\text {it }}$ unit variable cost of production for item $\mathrm{i}$ in a period of time $\mathrm{t}$

- $\mathrm{cq}_{\text {it }}$ unit inventory holding cost for the item $\mathrm{i}$ in time period t.

The five steps will present an analysis for a period of time comparing the old production data from the database. The analysis will try to decide if the new order for production is viable in this period of time and if it is not. In this case the data base integrate system will propose, based on the previous production plans a better solution.

\section{CONCLUSION}

The proposed solution for developing a production planning strategies using a data base integrated system can be a great support to measure alternative production scenarios or may quantify the effect of a production decision. The proposed solution has two important advantages:

- the solution could answer to a lot of production problems;

- the solution corresponds with the practical necessities in production systems in rapport with the final user, the engineer.

\section{REFERENCES}

Ghodsypour, S.H.; O'Brien. C. (1998), A decision support system for supplier selection using an integrated analytic hierarchy process and linear programming, International Journal of Production Economics, Vol. 56-57, No. 1, (September 1998) Pages 199-212

Lixin, T.; Jiyin, L.; Aiying, R.; Zihou Y. (2001). A review of planning and scheduling systems and methods for integrated steel production, European Journal of Operational Research, Vol. 133, No. 1,(August 2001) Pages 1-20

Mohora, C.; Anania, D.; Calin O.A. (2009). Simulations strategies using DELMIA Quest, Annals of DAAAM for 2009\&Proceedings of The 20th International DAAAM Symposium "Intelligent Manufacturing \& Automation: Theory, Practice \& Education" 25-28th November, 2009, Vienna, Austria, Volume 20, No.1, ISSN 1726-9679, ISBN 978-3-901509-70-4, pp. 0335-0336, Editor B. Katalinic, Published by DAAAM International, Vienna, Austria, 2009

Parag, C. P. (1997), A fuzzy linear programming model for production planning in coal mines, Computers \& Operations Research, Vol. 24, No. 12,( December 1997) Pages 1141-1149

Peterson, R.; Silver, E.A. (1997). Decision systems for inventory management and production planning, Wiley, ISBN 0471683272, New York 